\title{
Huden og hodet
}

\author{
Studier viser at det er en sammenheng mellom kroniske hudsykdommer \\ og psykiske lidelser. Nå er Norsk Forening for Psykodermatologi stiftet, \\ for å spre kunnskap om fagfeltet.
}

\section{«Sammenhengen mellom hudsykdom og psykiske lidelser er sterkere enn man tidligere har trodd»}

- Sammenhengen mellom hudsykdom og psykiske lidelser er sterkere enn man tidligere har trodd. Vi ser blant annet en sterk sammenheng $\mathrm{i}$ forhold til hudsymptomet kløe og psykiske plager (1). Blant pasienter med sterk kløe er selvmordstanker ikke uvanlig. Det er derfor viktig å ha mer søkelys på feltet. Mange kan trenge en form for psykisk intervensjon for å bli friske, sier psykiater og samfunnsmedisiner Lars Lien.

Han sitter i styret i Norsk Forening for Psykodermatologi, som ble stiftet 7. mars 2014. De skriver i en pressemelding at de har som formål å spre kunnskap om fagfeltet psykodermatologi, fremme og støtte utdanning og forskning, og organisere møter og kongresser omkring fagområdet. De vil også jobbe for aktivt samarbeid med og mellom organisasjoner, virksomheter og enkeltpersoner med interesser innenfor området.
- Vi tror det er et stort behov for å lære opp dermatologene og andre leger som jobber med denne pasientgruppen, slik at de kan hjelpe pasienter som sliter psykisk. I utgangspunktet tror vi dermatologene kan behandle dette ved hjelp av enkle kognitive teknikker. I noen tilfeller kan det være aktuelt å henvise til psykiater eller psyko$\log$, forteller Lien. Med seg i styret har han Florence Dalgard og Theis Huldt-Nystrøm som leder.

\section{Eline Feiring}

Tidsskriftet

\section{Litteratur}

1. Halvorsen JA, Lien L, Dalgard F et al. Suicidal ideation, mental health problems, and social function in adolescents with eczema: a population-based study. Journal of Investigative Dermatology 2014; e-publisert 4.2.

\section{Pasienttrygghetsprisen til arbeid med hjerneslag}

Helse Vests Pasienttrygghetspris 2014 (tidligere Kvalitetsprisen) er tildelt seksjonsoverlege Martin Kurz (f. 1975) og hans medarbeidere på Nevrosenteret ved Stavanger universitetssjukehus for arbeidet med å skape et sømløst pasientforløp for pasienter med hjerneslag.

Hvert år blir rundt 16000 nordmenn rammet av hjerneslag. Det fører ofte til invaliditet og til at pasienten havner på sykehjem. Et hjerneslag rammer ofte uten forvarsel, og for å oppnå et godt resultat er det avgjørende at hjerneslagpasienter får behandling så raskt som mulig.

Etter initiativ fra Nevrosenteret ved seksjonsoverlege Martin Kurz er det utviklet et pasientforløp som kutter tiden fra AMK er varslet til innleggelse i sykehus og behandlingsstart. Hele behandlingskjeden er i flere år blitt systematisk gjennomgått og forbedret.

Pasienttrygghetsprisen deles ut til fagmiljøer, grupper eller enkeltpersoner i Helse Vest som gjennom sitt forsknings- og utviklingsarbeid har økt kvaliteten på tjenestetilbudet i spesialisthelsetjenesten. Resultatene skal være dokumentert og publisert i fagtidsskrifter eller i vitenskapelige tidsskrifter.

Prisen består av 100000 kroner, et diplom og et kunstverk, og pengene skal benyttes til videre forsknings- og utviklingsprosjekter.

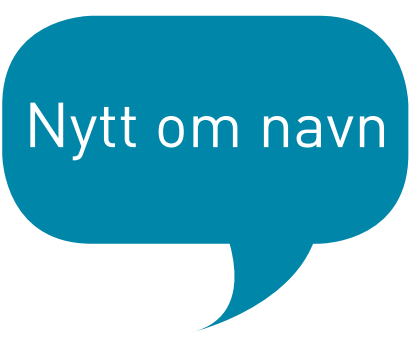

Svein Håvard Ålien er lege. Han har siden sommeren i fjor jobbet hos Sentrumslegene i Bodø og ble kåret til Bodøs beste lege på Legelisten.no. 30 pasienter ga ham toppkarakter (An.no).

Anders H. Christensen er lege i spesialisering og tillitsvalgt. Han jobber ved barneavdelingen på Drammen sykehus og ble vara for hovedtillitsvalgt for to år siden. Han beskriver sine oppgaver som å være «et bindeledd mellom yngre leger og ledelsen» (ylf.no).

Stein Husebø er lege. Han mener at om aktiv dødshjelp blir legalisert, vil det være fare for at mennesker som egentlig ikke ber om aktiv dødshjelp, får det (tb.no).

Ingrid Roscher er overlege ved Hudavdelingen ved Oslo universitetssykehus. Hun mener at det burde være mulig for folk å undersøke huden sin selv og komme tidligere til lege hvis man bare vet hva man skal se etter. Dette sier hun til NRK i forbindelse med at dødeligheten i Norge grunnet føflekkreft er høyere enn land vi sammenlikner oss med. 